\title{
Carbon Dioxide Enrichment in 'Virosa' Tomato Plant: Responses to Enrichment Duration and to Temperature
}

\author{
M. Hossein Behboudian ${ }^{1}$ \\ Department of Plant Science, Massey University, Palmerston North, \\ New Zealand
}

\author{
Robert Lai ${ }^{2}$ \\ The Horticulture and Food Research Institute of New Zealand (HortResearch), \\ Palmerston North, New Zealand
}

Additional index words. Lycopersicon esculentum, photosynthesis, transpiration, mineral nutrition, dark respiration

\begin{abstract}
Responses of the tomato (Lycopersicon esculentum Mill. cv. Virosa) plant to elevated $\mathrm{CO}_{2}$ concentrations applied throughout the photoperiod or part of it were studied under two temperature regimes. Plants were exposed to $\mathrm{CO}_{2}$ at 340 (control), 700, and 1000 $\mu \mathrm{lliter}{ }^{-1}$. The highest concentration was applied only at 22/16C (day/night) and $700 \mu \mathrm{l} \cdot \mathrm{liter}^{-1}$ at $22 / 16 \mathrm{C}$ and $25 / 16 \mathrm{C}$. Transpiration rates were lower and photosynthetic rates were higher under elevated $\mathrm{CO}_{2}$ than at the ambient level. Biomass production was higher only for plants grown at $700 \mu \mathrm{l} \cdot \mathrm{liter}^{-1}$ and 25/16C. Concentrations of macronutrients were lower in plants exposed to $1000 \mu \mathrm{l} \mathrm{CO} /$ /liter than in the control plants. Intermittent $\mathrm{CO}_{2}$ was applied using two timing methods. In method 1, plants were exposed to 4- or 8-hour high$\mathrm{CO}_{2}$ concentrations during their 12-hour photoperiod. In method 2, plants were exposed for 3.5 days of each week to $700 \mu \mathrm{ICO}_{2}$ /liter. Only two of the 8-hour exposures resulted in greater growth than the controls. The lack of higher growth for $\mathrm{CO}_{2}$-enriched plants at 22/ 16C was attributed to a higher dark respiration rate and to a lack of efficient transport of photosynthates out of leaves.
\end{abstract}

Carbon dioxide enrichment is a common practice in protected cultivation of tomatoes (Nederhoff and De Graaf, 1993). Although its effects on growth, yield, and physiological attributes of the plant have been researched extensively, there are aspects of $\mathrm{CO}_{2}$ enrichment that have been relatively neglected. These aspects, which we focused on, include intermittent $\mathrm{CO}_{2}$ application and interaction with temperature (Mortensen, 1987). These variables have economic implications for production. We hypothesized that $\mathrm{CO}_{2}$ enrichment is more beneficial during the early hours of the photoperiod than during middle or late hours. If this is true, enrichment throughout the entire photoperiod could be obviated. This hypothesis was based on a previous finding that photosynthetic rate was maximal during early hours in a constant environment (Behboudian, 1977), similar to the experimental conditions of this study.

Received for publication 8 Mar. 1994. Accepted for publication 8 July 1994. Mention of trade names does not constitute a guarantee or warranty of the products by Massey Univ. or HortResearch, nor does it imply endorsement of similar commercial products. The cost of publishing this paper was defrayed in part by the payment of page charges. Under postal regulations, this paper therefore must be hereby marked advertisement solely to indicate this fact.

${ }^{1}$ Senior Lecturer. To whom reprint requests should be addressed.

${ }^{2}$ Research Scientist. Current address: P.O. Box 7220, Cloisters Square, Perth, WA 6000, Australia.
$\mathrm{As}_{2}$ inhibition of photosynthesis increases with temperature, the effect of $\mathrm{CO}_{2}$ enrichment will increase with increasing temperature within a certain range (Mortensen, 1987). Growers are often advised to increase ventilation temperature by 2 to $4 \mathrm{C}$ when $\mathrm{CO}_{2}$ enrichment is used (Mortensen, 1987). However, data on temperature responses of plants under $\mathrm{CO}_{2}$ enrichment are scarce (Rozema, 1993), and temperature programs for various greenhouse crops should be reassessed (Mortensen, 1987). Therefore, we studied tomato plant responses to elevated $\mathrm{CO}_{2}$ with a $3 \mathrm{C}$ difference in day temperature. 'Virosa' was used because it is a popular greenhouse cultivar in New Zealand. In these initial studies, the focus was on early vegetative growth.

\section{Materials and Methods}

These experiments were performed in the National Climate Laboratory at HortResearch, Palmerston North, New Zealand. For each experiment, seedlings were transplanted singly into 4.4-liter plastic pots containing sterilized $70 \%$ coarse sand, $15 \%$ vermiculite, $15 \%$ peat growing medium. Plants were kept in a shadehouse for 1 week before being transferred to the appropriate walk-in controlledenvironment room. One room was assigned to each $\mathrm{CO}_{2}$-temperature treatment and up to four were used simultaneously. The position of the plants, which were placed on trolleys in each room, was rotated twice a week within the trolley and the trolleys were also rotated in the room. Nights were at $16 \pm 0.5 \mathrm{C}$ in all experiments and the days were either $22 \pm$ $0.5 \mathrm{C}$ or $25 \pm 0.5 \mathrm{C}$, depending on the experiment. Relative humidity was kept at $70 \% \pm$ $5 \%$. Average photosynthetic photon flux (PPF) was $710 \mu \mathrm{mol} \cdot \mathrm{m}^{-2} \cdot \mathrm{s}^{-1}$ at the plant level. The lighting system for each room consisted of $4 \times$ 1000-W Sylvania Metalarc high-pressure discharge lamps (GTE Products Corp., Manchester, N.H.) together with $4 \times 1000$-W Philips tungsten iodide lamps. The photoperiod was from 0900 to $2100 \mathrm{HR}$. Plants were irrigated at 0600,1800 , and 2400 HR with a mineral nutrient solution supplied by an automatic application system. The solution contained (in ppm) 105.1 N, 15.5 P, 119.0 K, 32.1 S, 100.2 Ca, 2.1 Fe, 24.3 Mg, 0.25 B, 0.25 Mn, 0.01 Cu, 0.02 $\mathrm{Zn}, 0.005 \mathrm{Mo}, 1.8 \mathrm{Cl}$, and $1.02 \mathrm{Na}$. Normal $\mathrm{CO}_{2}$ concentration for control plants was 340 , and for enriched treatments it was either 700 or $1000 \mu \mathrm{l} \cdot$ liter $^{-1}$. Enrichment was achieved by using bottled food-grade $\mathrm{CO}_{2}$ regulated by a solenoid and controlled to within $50 \mu$ l. liter $^{-1}$ of the set point by a Binos-1 infrared gas analyzer (Leybold-Heraeus $\mathrm{GmbH}$, Hanau, Germany). Intermittent $\mathrm{CO}_{2}$ was applied by one of two timing methods. In method 1 , plants were exposed to a $\mathrm{CO}_{2}$ enrichment during either their first, second, or third $4 \mathrm{~h}$ of the 12-h photoperiod. In addition, 8-h exposures also were used by a combination of any two of the 4-h intervals. In method 2, plants were kept for 3.5 days of each week in the high- $\mathrm{CO}_{2}\left(700 \mu l \cdot l i t \mathrm{r}^{-1}\right)$ room and for the remainder of the week in the ambient- $\mathrm{CO}_{2}$ room.

Photosynthesis, transpiration, and dark respiration were measured on the youngest fully expanded single leaves, using a LI-COR 6200 system(LI-COR, Lincoln, Neb.). Whole-plant transpiration was measured gravimetrically. Leaf area was determined using a LI-COR 3100 area meter. Concentration of macronutrients was measured in the top eight leaves, which were dried at $65 \mathrm{C}$ before they were ground, using one sample per plant. Nitrogen was analyzed by Kjeldahl digestion and colorimetry; $\mathrm{P}$ by sulphuric acid digestion and colorimetry; $\mathrm{K}, \mathrm{Mg}$, and $\mathrm{Ca}$ by nitric acid digestion and either atomic absorption or emission spectrophotometry; and S by sodium hypobromite digestion followed by hydrogen sulphide reduction and colorimetry. This research consisted of several experiments, the specifics of each are presented with the results for clarity. The $t$ test was used for comparison of two means, and analysis of variance was used for comparing several means. These analyses were done using Minitab and SAS statistical packages.

\section{Results}

The first experiment on intermittent application of $1000 \mu \mathrm{CO}_{2} /$ liter showed that 4 -h exposures neither increased total plant dry mass nor leaf area compared to the ambient control (Table 1). Leaf expansion was restricted in the continuously enriched treatment. Two of the 8-h exposures resulted in higher plant dry mass than the control. We 
then tested whether the lack of response to enrichment in this experiment might have been due to either the mode of intermittent $\mathrm{CO}_{2}$ application (as discussed below) or to the $\mathrm{CO}_{2}$ concentration used $\left(1000 \mu \mathrm{l} \cdot\right.$ liter $\left.^{-1}\right)$. We investigated these alternatives by holding plants either in normal $\left(340 \mu 1 \cdot\right.$ liter $\left.^{-1}\right)$ or high (700 $\mu l \cdot$ liter $\left.^{-1}\right) \mathrm{CO}_{2}$ levels, or for half the week at the normal level followed by half the week at the high- $\mathrm{CO}_{2}$ level. The day/night cycle was again $22 / 16 \mathrm{C}$. After 37 days, the leaf areas $\left(\mathrm{m}^{2} \pm \mathrm{sE}\right.$, $\mathrm{n}=5$ ) for control, continuously enriched (photoperiod only), and partially enriched treatments were $0.91 \pm 0.03,0.71 \pm 0.03$, and 0.88 \pm 0.04 , respectively. The corresponding plant dry masses $(\mathrm{g} \pm \mathrm{SE})$ were $91.5 \pm 5.1,102.4 \pm$ 4.8, and $90.7 \pm 2.2$. Continuous enrichment significantly reduced leaf area compared to the other two treatments. A possible reason for the lack of a positive response to elevated $\mathrm{CO}_{2}$ was the limited growth potential under the low day temperature. Therefore, the initial experiment (Table 1) was repeated with $25 \mathrm{C}$ days. In these conditions, leaf area was significantly smaller with all elevated $\mathrm{CO}_{2}$ concentrations, as was total plant dry mass with 4-h exposures, compared to the control (Table 2). Continuous exposure to elevated $\mathrm{CO}_{2}$ resulted in a significant increase in total plant dry mass.

Further treatments were imposed to determine if plant growth, in terms of dry mass, was improved under some durations of elevated $\mathrm{CO}_{2}$ and increased temperature. With $25 \mathrm{C}$ days, a significant increase of shoot dry mass occurred at $700 \mu \mathrm{lCO}_{2}$ /liter compared to ambient (Table 3 ). In contrast, with elevated $\mathrm{CO}_{2}$ and $22 \mathrm{C}$ days, root dry mass was higher than the control. Leaf area was reduced with plants exposed to elevated $\mathrm{CO}_{2}$ at both temperatures.

Whole-plant and single-leaf transpiration were always significantly lower at the elevated $\mathrm{CO}_{2}$ concentration compared to the ambient in either $22 / 16 \mathrm{C}$ or $25 / 16 \mathrm{C}$ (day/ night). For example, whole-plant rates $\left(\mathrm{kg} \cdot \mathrm{m}^{-2} \cdot \mathrm{s}^{-1}\right.$ $\times 10^{6} \pm$ sE, $\mathrm{n}=8$ ) in $700 \mu \mathrm{lCO}_{2} /$ liter at $22 / 16 \mathrm{C}$ (day/night) were 18.2 $\pm 1.19,22.8 \pm 1.08$, and $16.6 \pm 0.67$ for hour 1 , hour 5 , and hour 9 of the photoperiod, respectively; the corresponding values for plants at $340 \mu \mathrm{l} \mathrm{CO} /$ liter were 25.3 $\pm 0.75,28.7 \pm 0.72$, and $26.3 \pm 0.81$. Photosynthesis of plants at the differing $\mathrm{CO}_{2}$ and day temperature treatments was measured at various stages during the photoperiod. On one occasion, the values for plants in $1000 \mu \mathrm{CO}_{2} /$ liter and 22/16C (day/night) were 20.4, 21.3, and $21.9 \mu \mathrm{mol} \cdot \mathrm{m}^{-2} \cdot \mathrm{s}^{-1}$ for hour 1 , hour 5 , and hour 10 of the photoperiod, respectively; the corresponding values for plants in the ambient $\mathrm{CO}_{2}$ concentration were $13.6,13.7$, and 13.2 $\mu \mathrm{mol} \cdot \mathrm{m}^{-2} \cdot \mathrm{s}^{-1}$. The differences between ambient and elevated $\mathrm{CO}_{2}$ were highly significant $(P \leq 0.01)$. For plants growing in $700 \mu \mathrm{CO}_{2} /$ liter and with days of $25 \mathrm{C}$, photosynthetic rates for the above hours were $22.4,20.2$, and $21.5 \mu \mathrm{mol} \cdot \mathrm{m}^{-2} \cdot \mathrm{s}^{-1}$, respectively; the corresponding values for the control plants were 11.7, 12.0 , and $15.0 \mu \mathrm{mol} \cdot \mathrm{m}^{-2} \cdot \mathrm{s}^{-1}$, with the same differences being significant at $P \leq 0.01$. With intermittent $\mathrm{CO}_{2}$ exposures, photosynthesis of plants during exposure to the elevated $\mathrm{CO}_{2}$ concentration was significantly higher than the values measured during the exposure to the ambient $\mathrm{CO}_{2}$ concentration (Fig.1). Dark respiration rates (measured during the fourth hour of the dark period under ambient conditions) for plants exposed to daytime $\mathrm{CO}_{2}$ concentrations of 340 or $700 \mu 1 \cdot l_{\text {liter }}^{-1}$ were $2.7 \pm 0.2$ and $4.1 \pm 0.7 \mu \mathrm{mol} \cdot \mathrm{m}^{-2} \cdot \mathrm{s}^{-1}$, respectively.

No visual nutrient deficiency symptoms were observed in any plants. However, concentrations (on a dry-weight basis) of N, P, K, $\mathrm{S}, \mathrm{Ca}$, and $\mathrm{Mg}$ in recently matured leaves were significantly lower in plants grown with $\mathrm{CO}_{2}$ at 1000 than at $340 \mu \mathrm{l} \cdot$ liter $^{-1}$ (Table 4 ).

\section{Discussion}

Plants grown with days at $22 \mathrm{C}$ were generally characterized by a lack of growth response to $\mathrm{CO}_{2}$ enrichment, despite having significantly higher photosynthetic rates, possibly because of acclimation of photosynthesis under prolonged $\mathrm{CO}_{2}$ enrichment, as previously reported in tomatoes (Besford, 1993; Yelle et al., 1989, 1990). A striking feature of our research was the smaller leaf area in $\mathrm{CO}_{2}-$ enriched plants than in control plants (Tables

Table 1. Growth responses of tomatoes to ambient $\left(\mathrm{A}, 340 \mu \mathrm{l} \cdot \mathrm{liter}^{-1}\right)$ or high $\left(\mathrm{H}, 1000 \mu \mathrm{l} \cdot\right.$ liter $\left.^{-1}\right) \mathrm{CO}_{2}$ concentrations in a 12-h photoperiod, either in the first $(\mathrm{H}, \mathrm{A}, \mathrm{A})$, second $(\mathrm{A}, \mathrm{H}, \mathrm{A})$, or third $(\mathrm{A}, \mathrm{A}, \mathrm{H})$ $4 \mathrm{~h}$, or in a combination of these.

\begin{tabular}{lllcc}
\hline \hline & $\begin{array}{c}\text { Leaf } \\
\mathrm{area}^{\mathrm{z}} \\
\left(\mathrm{m}^{2}\right)\end{array}$ & $\begin{array}{c}\text { Total plant } \\
(\mathrm{g})\end{array}$ & $\begin{array}{c}\text { Dry mass } \\
(\mathrm{g})\end{array}$ & $\begin{array}{c}\text { Root } \\
(\mathrm{g})\end{array}$ \\
\hline Treatment & $0.12 \mathrm{ab}^{\mathrm{y}}$ & $11.6 \mathrm{~cd}^{\mathrm{x}}$ & $10.3 \mathrm{bc}^{\mathrm{x}}$ & $1.3 \mathrm{a}^{\mathrm{x}}$ \\
$\mathrm{A}, \mathrm{A}, \mathrm{A}$ & $0.11 \mathrm{~b}$ & $12.4 \mathrm{a}-\mathrm{d}$ & $11.1 \mathrm{a}-\mathrm{c}$ & $1.3 \mathrm{a}$ \\
$\mathrm{H}, \mathrm{H}, \mathrm{H}$ & $0.12 \mathrm{ab}$ & $12.0 \mathrm{~b}-\mathrm{d}$ & $10.5 \mathrm{bc}$ & $1.5 \mathrm{a}$ \\
$\mathrm{H}, \mathrm{A}, \mathrm{A}$ & $0.12 \mathrm{ab}$ & $11.3 \mathrm{~d}$ & $9.9 \mathrm{c}$ & $1.4 \mathrm{a}$ \\
$\mathrm{A}, \mathrm{H}, \mathrm{A}$ & $0.12 \mathrm{ab}$ & $12.3 \mathrm{a}-\mathrm{d}$ & $10.7 \mathrm{a}-\mathrm{c}$ & $1.6 \mathrm{a}$ \\
$\mathrm{A}, \mathrm{A}, \mathrm{H}$ & $0.12 \mathrm{ab}$ & $13.3 \mathrm{ab}$ & $11.8 \mathrm{a}$ & $1.5 \mathrm{a}$ \\
$\mathrm{H}, \mathrm{H}, \mathrm{A}$ & $0.12 \mathrm{ab}$ & $13.6 \mathrm{a}$ & $12.0 \mathrm{a}$ & $1.6 \mathrm{a}$ \\
$\mathrm{H}, \mathrm{A}, \mathrm{H}$ & $0.12 \mathrm{ab}$ & $13.2 \mathrm{a}-\mathrm{c}$ & $11.6 \mathrm{ab}$ & $1.6 \mathrm{a}$ \\
$\mathrm{A}, \mathrm{H}, \mathrm{H}$ & & &
\end{tabular}

${ }^{2}$ Means of eight replicate plants.

yEnrichment occurred for 20 days at 22/16C (day/night)

xMean separation within each column by Duncan's multiple range test, $P \leq 0.05$.

Table 2. Growth responses of tomatoes to ambient $\left(\mathrm{A}, 340 \mu \mathrm{l} \cdot \mathrm{liter}^{-1}\right)$ or high $\left(\mathrm{H}, 700 \mu 1 \cdot\right.$ liter $\left.^{-1}\right) \mathrm{CO}_{2}$ concentrations in a 12-h photoperiod, either in their first $(\mathrm{H}, \mathrm{A}, \mathrm{A})$, second $(\mathrm{A}, \mathrm{H}, \mathrm{A})$, or third $(\mathrm{A}, \mathrm{A}, \mathrm{H})$ $4 \mathrm{~h}$. Plants were 64 days old from seeding at harvest.

\begin{tabular}{lcccc}
\hline \hline & $\begin{array}{c}\text { Leaf } \\
\text { area } \\
\left(\mathrm{m}^{2}\right)\end{array}$ & $\begin{array}{c}\text { Total plant } \\
(\mathrm{g})\end{array}$ & $\begin{array}{c}\text { Shoot } \\
(\mathrm{g})\end{array}$ & $\begin{array}{c}\text { Doot } \\
(\mathrm{g})\end{array}$ \\
\cline { 2 - 4 } Treatment $^{\mathrm{y}}$ & $0.61 \mathrm{a}^{\mathrm{x}}$ & $58.5 \mathrm{~b}^{\mathrm{x}}$ & $51.5 \mathrm{~b}^{\mathrm{x}}$ & $7.1 \mathrm{a}^{\mathrm{x}}$ \\
$\mathrm{A}, \mathrm{A}, \mathrm{A}$ & $0.45 \mathrm{~b}$ & $65.5 \mathrm{a}$ & $57.3 \mathrm{a}$ & $8.2 \mathrm{a}$ \\
$\mathrm{H}, \mathrm{H}, \mathrm{H}$ & $0.47 \mathrm{~b}$ & $52.2 \mathrm{c}$ & $44.9 \mathrm{c}$ & $7.4 \mathrm{a}$ \\
$\mathrm{H}, \mathrm{A}, \mathrm{A}$ & $0.47 \mathrm{~b}$ & $49.9 \mathrm{c}$ & $42.4 \mathrm{c}$ & $7.2 \mathrm{a}$ \\
$\mathrm{A}, \mathrm{H}, \mathrm{A}$ & $0.46 \mathrm{~b}$ & $49.9 \mathrm{c}$ & $43.5 \mathrm{c}$ & $6.4 \mathrm{a}$ \\
$\mathrm{A}, \mathrm{A}, \mathrm{H}$ & & &
\end{tabular}

${ }^{2}$ Means of eight replicate plants.

yEnrichment was for 30 days at $25 / 16 \mathrm{C}$ (day/night).

${ }^{\times}$Mean separation within each column by Duncan's multiple range test, $P \leq 0.05$.

Table 3. Growth responses of tomatoes to elevated $\mathrm{CO}_{2}$ at two-day temperature regimes of 22 or $25 \mathrm{C}$ (night temperature $=16 \mathrm{C}$ ). Plants were 64 days old from seeding at harvest.

\begin{tabular}{|c|c|c|c|c|c|c|}
\hline \multirow{2}{*}{$\begin{array}{l}\mathrm{CO}_{2} \\
\text { concn } \\
\left(\mu \mathrm{l} \cdot \text { liter }^{-1}\right)\end{array}$} & \multirow[b]{2}{*}{$\begin{array}{c}\text { Temp } \\
\left({ }^{\circ} \mathrm{C}\right)\end{array}$} & \multirow{2}{*}{$\begin{array}{l}\text { Leaf } \\
\text { area }^{y} \\
\left(\mathrm{~m}^{2}\right)\end{array}$} & \multicolumn{2}{|c|}{ Dry mass $^{z}$} & \multirow{2}{*}{$\begin{array}{c}\text { No. } \\
\text { flower } \\
\text { trusses }^{2}\end{array}$} & \multirow[b]{2}{*}{$\begin{array}{c}\text { No. } \\
\text { laterals }\end{array}$} \\
\hline & & & $\begin{array}{c}\text { Shoot } \\
(\mathrm{g})\end{array}$ & $\begin{array}{l}\text { Root } \\
(\mathrm{g})\end{array}$ & & \\
\hline 340 & 25 & $0.61 \mathrm{ab}^{\mathrm{x}}$ & $51.4 b^{x}$ & $7.1 b^{x}$ & $7.3 \mathrm{a}^{\mathrm{x}}$ & $6.1 \mathrm{a}^{\mathrm{x}}$ \\
\hline 700 & 25 & $0.45 \mathrm{c}$ & $58.0 \mathrm{a}$ & $8.3 \mathrm{ab}$ & $7.1 \mathrm{a}$ & $6.1 \mathrm{a}$ \\
\hline 340 & 22 & $0.64 \mathrm{a}$ & $55.5 \mathrm{ab}$ & $10.5 \mathrm{a}$ & $4.9 \mathrm{~b}$ & $7.7 \mathrm{a}$ \\
\hline 700 & 22 & $0.54 \mathrm{~b}$ & $55.1 \mathrm{ab}$ & $11.0 \mathrm{a}$ & $4.3 \mathrm{~b}$ & $6.6 \mathrm{a}$ \\
\hline
\end{tabular}

${ }^{2}$ Means of eight replicate plants.

yEnrichment was for 31 days.

${ }^{x}$ Mean separation within each column by Duncan's multiple range test, $P \leq 0.05$. 


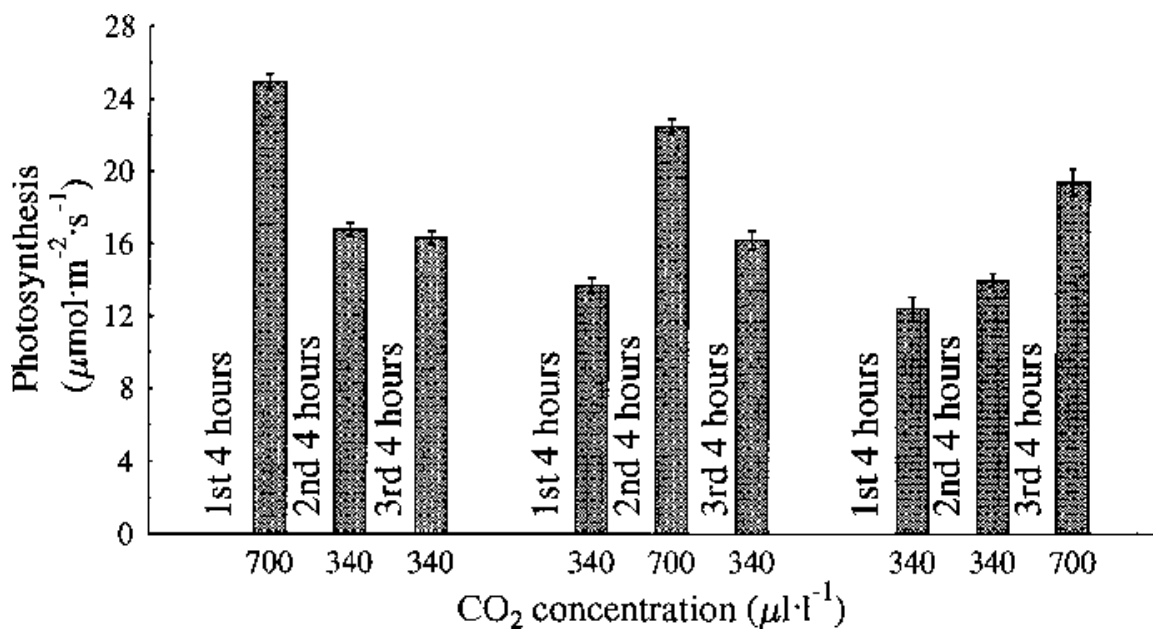

Fig.1. Effect of air $\mathrm{CO}_{2}$ concentration on photosynthesis in single leaves of tomato during a 12-h photoperiod. Exposure to elevated $\mathrm{CO}_{2}\left(700 \mu l \cdot l i t r^{-1}\right)$ occurred during either the first (left), second (center), or third (right) $4 \mathrm{~h}$ of the photoperiod. For the remaining $8 \mathrm{~h}$, the plants were exposed to ambient $\mathrm{CO}_{2}$ concentration $\left(340 \mu \mathrm{l} \cdot\right.$ liter $\left.^{-1}\right)$. Plants were grown at $25 / 16 \mathrm{C}$ (day/night). Carbon dioxide enrichment was applied over 30 days. Bars on histograms represent twice standard error of means, based on eight replicate plants.

Table 4. Concentration (percent dry weight) of N, P, K, S, Ca, and Mg in tomato leaves at ambient (340 $\mu \mathrm{l} \cdot$ liter $^{-1}$ ) and at $1000 \mu 1 \mathrm{CO}_{2} /$ liter at 22/16C (day/night). Plants were 64 days old from seeding at harvest.

\begin{tabular}{lcccccc}
\hline \hline $\begin{array}{l}\mathrm{CO}_{2} \\
\text { concn }\end{array}$ & \multicolumn{5}{c}{ Nutrient } \\
\cline { 2 - 7 }$\left(\mu l \cdot\right.$ liter $\left.^{-1}\right)$ & $\mathrm{N}$ & $\mathrm{P}$ & $\mathrm{K}$ & $\mathrm{S}$ & $\mathrm{Ca}$ & $\mathrm{Mg}$ \\
\hline 340 & $2.57 \pm 0.12^{\mathrm{z}}$ & $0.18 \pm 0.01^{\mathrm{z}}$ & $2.96 \pm 0.15^{\mathrm{z}}$ & $0.56 \pm 0.04^{\mathrm{z}}$ & $1.88 \pm 0.09^{\mathrm{z}}$ & $0.54 \pm 0.03^{\mathrm{z}}$ \\
$1000^{\mathrm{y}}$ & $1.42 \pm 0.05$ & $0.12 \pm 0.01$ & $1.81 \pm 0.05$ & $0.31 \pm 0.03$ & $1.26 \pm 0.11$ & $0.37 \pm 0.03$ \\
\hline
\end{tabular}

${ }^{\mathrm{z}}$ Means of 10 replicate plants $\pm \mathrm{SE}$.

yEnrichment was for 31 days.

10 min with ${ }^{14} \mathrm{CO}_{2}$ between the second and third hours of the photoperiod and then measured the proportion of ${ }^{14} \mathrm{C}$-labeled assimilates after $30 \mathrm{~min}, 3 \mathrm{~h}$, and at the end of light and dark periods in leaves $8,9,10$, and truss 1 . For all these measurement times, leaf 10 had a lower proportion of ${ }^{14} \mathrm{C}$-labeled assimilates in control than in $\mathrm{CO}_{2}$-enriched plants, while the opposite was true for the other organs. A lower rate of translocation in enriched than in control plants is a possible reason for the lack of positive growth response to $\mathrm{CO}_{2}$ enrichment. Rozema (1993) observed that the higher photosynthetic rate for wheat at 700 than at $350 \mu \mathrm{l}$ $\mathrm{CO}_{2} /$ liter did not result in a higher growth rate for the former treatment. He hypothesized that a lower translocation rate at the prevailing low temperature (10-14C) might have been the reason. In our $\mathrm{CO}_{2}$-enriched plants, photosynthates accumulated in leaves as reserves rather than contributing to leaf expansion, as also observed previously by Yelle et al. (1990) for two species of tomato.

The lower transpiration rate at the elevated $\mathrm{CO}_{2}$ concentration is solely due to stomatal closure, as shown by Nederhoff and De Graaf (1993), whose analysis included other environmental factors affecting transpiration, such as radiation, air humidity, and leaf temperature. They concluded that stomatal conductance of tomatoes decreases by $\approx 3 \%$ for every $100-\mu 1 \cdot$ liter $^{-1}$ increase in $\mathrm{CO}_{2}$ concentration in the range of 300 to $1200 \mu \mathrm{l} \cdot$ liter $^{-1}$. The lower concentration of macronutrients (Table 4) in the $\mathrm{CO}_{2}$-enriched plants is associated with
1991). However, McConnaughay et al. (1993) questioned the relevance of the root restriction- $\mathrm{CO}_{2}$ enrichment hypothesis without paying due attention to the nutritional status of the plant that was overlooked in some studies. We did not regard root restriction as being a problem in our experiment. The 4.4-liter pots were much bigger than those used in some rootrestriction studies (McConnaughay et al., 1993; Thomas and Strain, 1991), and in some experiments the root mass was too small (Table 1) to have been restricted by 4.4-liter pots.

At $25 \mathrm{C}, \mathrm{CO}_{2}$ at $700 \mu \mathrm{l} \cdot$ liter $^{-1}$ resulted in greater plant dry-matter accumulation than at $22 \mathrm{C}$, with the increase occurring in shoots and not in roots (Table 3 ). However, control plants growing in ambient $\mathrm{CO}_{2}$ concentration at $22 \mathrm{C}$ produced more dry matter than those at $25 \mathrm{C}$. The lower temperature appears to be better for total dry-matter production with this cultivar under ambient $\mathrm{CO}_{2}$, but a higher temperature should be used if $\mathrm{CO}_{2}$ enrichment is adopted. This recommendation supports the statement by Mortensen (1987) that, under elevated $\mathrm{CO}_{2}$ concentration, optimum temperature for growth is increased.

Commercial enrichment of $\mathrm{CO}_{2}$ is normally carried out for the entire photoperiod. In Great Britain, enrichment of commercially produced tomatoes is achieved by applying $1000 \mu \mathrm{CO}_{2} /$ liter from sunrise to $1.5 \mathrm{~h}$ before sunset (Slack, 1986). Provided similar results were produced, shorter durations of $\mathrm{CO}_{2}$ application would be an attractive economic alternative. This possibility was the basis of our intermittent $\mathrm{CO}_{2}$ experiments. At 22C, dry-matter production was unchanged by 4-h exposures to $1000 \mu \mathrm{l} \mathrm{CO}_{2}$ /liter compared to continuous exposure (Table 1). However, an 8-h exposure produced significantly higher dry matter than ambient $\mathrm{CO}_{2}$. With days at $25 \mathrm{C}$ and $\mathrm{CO}_{2}$ at $700 \mu$ l.liter ${ }^{-1}$, a 4-h exposure resulted in significantly less dry-matter production than the continuously exposed control (Table 2), although the photosynthetic rate during the enrichment period was significantly higher (Fig.1). Diminution of dry-matter production occurred possibly because of the manner in which the 4-h enrichment was imposed. Plants had to be shifted from the ambient to the high- $\mathrm{CO}_{2}$ room, which did not take more than 2 min. However, their stomata might have closed during the move and subsequently needed adjustment time in the high- $\mathrm{CO}_{2}$ conditions. Photosynthesis was measured $45 \mathrm{~min}$ after the plants were shifted. At the end of $4 \mathrm{~h}$, plants were shifted back to the ambient- $\mathrm{CO}_{2}$ conditions and had to undergo a similar adjustment. Possibly, the total photosynthetic production throughout the photoperiod for these plants was lower than the control plants, resulting in less growth. For plants undergoing the 8-h exposures (Table 1), the situation would have been redressed by longer exposure to higher $\mathrm{CO}_{2}$ concentration and a better opportunity for photosynthates to move out of leaves compared to the continuous enrichment.

Plants growing at $22 / 16 \mathrm{C}$ and $700 \mu \mathrm{CO}_{2} /$ liter for 3.5 days of each week did not produce more dry matter than those growing at ambient $\mathrm{CO}_{2}$. Continuous exposure to $700 \mu \mathrm{lCO}_{2} /$ liter 
resulted in significant increases in growth at $25 / 16 \mathrm{C}$ but not at $22 / 16 \mathrm{C}$ (day/night). One possibility is that the higher temperature improved translocation of photosynthates, thus producing more dry matter (Rozema, 1993).

Although $\mathrm{CO}_{2}$ enrichment is a common practice in greenhouse production of tomatoes, they might be less responsive than some other $\mathrm{C}_{3}$ plants. They ranked 18th in Poorter's (1993) review in which he compared $19 \mathrm{C}_{3}$ crop species in their response to enrichment (600-720 $\mu \mathrm{l} \cdot$ liter $^{-1}$ ). Poorter (1993) cited numerous studies, involving the same species, in which the degree of response differed, presumably reflecting cultivar differences. Lakso et al. (1984) reported marked cultivar difference in photosynthetic responses of tomato plants to enriched $\mathrm{CO}_{2}$ concentration. In our studies, 'Virosa' did not show favorable growth responses to enhanced $\mathrm{CO}_{2}$ concentrations at its optimal day temperature of $22 \mathrm{C}$. Although significant growth responses occurred at $25 \mathrm{C}$, the extra cost of doubling the $\mathrm{CO}_{2}$ concentration and raising the temperature might not have been compensated for by improved vegetative growth. However, the ultimate test of the variables we used must consider production of marketable fruit.

\section{Literature Cited}

Behboudian, M.H. 1977. Water relations of cucumber, tomato, and sweet pepper. Meded.
Landbouhogesch. Wageningen 77(6):1-84.

Behboudian, M.H. and D.R. Anderson. 1990. Effects of potassium deficiency on water relations and photosynthesis of the tomato plant. Plant \& Soil 127:137-139.

Besford, R.T. 1993. Photosynthesis acclimation in tomato plants in high $\mathrm{CO}_{2}$. Vegetatio 104/ 105:441-448.

Bunce, J.A. 1990. Short- and long-term inhibition of respiratory carbon dioxide efflux by elevated carbon dioxide. Ann. Bot. 65:637-642.

Glass, A.D.M. 1989. Plant nutrition: An introduction to current concepts. Jones and Bartlett, Boston.

Kimball, B.A., J.R. Mauney, F.S. Nakayama, and S.B. Idso. 1993. Effects of increasing atmospheric $\mathrm{CO}_{2}$ on vegetation. Vegetatio 104/ 105:65-75.

Kuehny, J.S., M.M. Peet, P.V. Nelson, and D.H. Willits. 1991. Nutrient dilution by starch in $\mathrm{CO}_{2}$-enriched chrysanthemum. J. Expt. Bot. 42:711-716.

Lakso, A.N., J.F. Bierhuizen, and G.F.P. Martakis. 1984. Light responses of photosynthesis and transpiration of two tomato cultivars under ambient and altered $\mathrm{CO}_{2}$ and $\mathrm{O}_{2}$. Scientia Hort. 23:119-128.

Madsen, E. 1975. Effect of $\mathrm{CO}_{2}$ enrichment on growth, development, fruit production and fruit quality of tomato from a physiological point of view, p. 318-330. In: P. Chouard and N. de Bilderling (eds.). Phytotronics in agricultural and horticultural research. Bordas, Paris.

McConnaughay, K.D.M., G.M. Bernston, and F.A. Bazzaz. 1993. Plant responses to carbon dioxide. Nature 361(1):24.
Mortensen, L.M. 1987. Review: $\mathrm{CO}_{2}$ enrichment in glasshouses. Crop responses. ScientiaHort. 33:125.

Nederhoff, E.M. and R. De Graaf. 1993. Effects of $\mathrm{CO}_{2}$ on leaf conductance and canopy of greenhouse grown cucumber and tomato. J. Hort. Sci. 68(6):925-937.

Poorter, H. 1993. Interspecific variation in the growth response of plants to an elevated ambient $\mathrm{CO}_{2}$ concentration. Vegetatio 104/105:77-97.

Rozema, J. 1993. Plant responses to atmospheric carbon dioxide enrichment: Interactions with some soil and atmospheric conditions. Vegetatio 104/105:173-190.

Slack, G. 1986. $\mathrm{CO}_{2}$ enrichment of tomato crops, p. 151-163. In: H.Z. Enoch and B.A. Kimball (eds.). Carbon dioxide enrichment of greenhouse crops. vol. II. Physiology, yield, and economics. CRC Press, Boca Raton, Fla.

Thomas, R.B. and B.R. Strain. 1991. Root restriction as a factor in photosynthetic acclimation of cotton seedlings grown in elevated carbon dioxide. Plant Physiol. 96:627-634.

Tripp, K.E., M.M. Peet, D.M. Pharr, D.H. Willits, and P.V. Nelson. 1991. $\mathrm{CO}_{2}$-enriched yield and foliar deformation among tomato genotypes in elevated $\mathrm{CO}_{2}$ environments. Plant Physiol. 96:713-719.

Yelle, S., R.C. Beeson, M.J. Trudel, and A. Gosselin 1989. Acclimation of two tomato species to high atmospheric $\mathrm{CO}_{2}$. I. Sugar and starch concentration. Plant Physiol. 90:1465-1472.

Yelle, S., R.C. Beeson, M.J. Trudel, and A. Gosselin. 1990. Duration of $\mathrm{CO}_{2}$ enrichment influences growth, yield, and gas exchange of two tomato species. J. Amer. Soc. Hort. Sci. 115(1):52-57. 